References

1. Lange, R. A. (2013). Can You Predict What Happens When EuroSCORE Weds Biomarker?. Journal of the American College of Cardiology, 61 (6), 682-684. doi: 10.1016/j.jacc.2012.11.028

2. Bootcov, M. R. (1997). MIC-1, a novel macrophage inhibitory cytokine, is a divergent member of the tgf-b superfamily. Proceedings of the National Academy of Sciences, 94 (21), 11514-11519. doi: 10.1073/pnas.94.21.11514

3. Wollert, K. C., Kempf, T., Peter, T., Olofsson, S., James, S., Johnston, N. et. al. (2007). Prognostic Value of Growth-Differentiation Factor-15 in Patients With Non-STElevation Acute Coronary Syndrome. Circulation, 115, 962-971. doi: 10.1161/circulationaha.106.650846

4. Xu, J. (2006). GDF15/MIC-1 functions as a protective and antihypertrophic factor released from the myocardium in association with SMAD protein activation. $\begin{array}{llll}\text { Circulation } & \text { Research, } 98 \quad \text { (3), } & 342-350 .\end{array}$ doi: 10.1161/01.res.0000202804.84885.d0

5. Bonaca, M. P., Morrow, D. A., Braunwald, E. (2011). Growth Differentiation Factor-15 And Risk Of Recurrent Events In Patients Stabilized After Acute Coronary Syndrome: Observations From PROVE IT-TIMI 22. Arteriosclerosis, Thrombosis, and Vascular Biology, 31, 203-210. doi: 10.1161/atvbaha.110.213512

6. Kempf, T., Sinning, J. M., Quint, A., Bickel, C., Sinning, C. et al. (2009). Growth differentiation factor-15 for risk stratification in patients with stable and unstable coronary heart disease: results from the AtheroGene study. Circulation: Cardiovascular Genetics, 2 (3), 286-292.

doi: 10.1161/circgenetics. 108.824870

7. Anand, I. S., Kempf, T., Rector, T. S., Tapken, H., Allhoff, T. et al. (2010). Serial measurement of growthdifferentiation factor-15 in heart failure: relation to disease severity and prognosis in the Valsartan Heart Failure Trial. Circulation, 122, 1387-1395.

doi: 10.1161/circulationaha.109.928846

8. Xu, J. (2006). Gdf15/mic-1 functions as a protective and antihypertrophic factor released from the myocardium in association with smad protein activation. Circulation Research, 98 (3), 342-350. doi: 10.1161/01.res.0000202804.84885.d0

9. Kempf, T., Zarbock, A, Widera, C, Butz, S. et al. (2011). GDF-15 is an inhibitor of leukocyte integrin activation required for survival after myocardial infarction in mice. Nature Medicine, 17 (5), 581-588. doi: 10.1038/nm.2354

Дата надходження рукопису 20.11.2014

Копица Николай Павлович, доктор медицинских наук, заслуженный врач Украины, заведующий отделом, Отдел острого инфаркта миокарда, Государственное Учреждение «Национальный Институт Терапии имени Л. Т. Малой Национальной академии медицинских наук Украины», пр. Постышева, 2-а, г. Харьков, Украина, 61039

E-mail:n_kopitsa@ukr.net

Вишневская Ирина Руслановна, младший научный сотрудник, Отдел острого инфаркта миокарда, Государственное Учреждение «Национальный Институт Терапии им. Л. Т. Малой Национальной академии медицинских наук Украины», пр. Постышева, 2-а, г. Харьков, Украина, 61039

E-mail:ivichenka@gmail.com

УДК: 616.34-008.6-036.1-06:616.233-007.272-02

DOI: 10.15587/2313-8416.2014.31506

\title{
ОСОБЛИВОСТІ КЛІНІЧНОГО ПЕРЕБІГУ СИНДРОМУ ПОДРАЗНЕНОГО КИШЕЧНИКУ У ПАЦІЕНТІВ НА БРОНХООБСТРУКТИВНУ ПАТОЛОГІЮ
}

\section{(C) С. В. Коваленко}

В статті розглядаються питання клінічного перебігу частої коморбідної патології - хронічного обструктивного захворювання легень, бронхіальної астми $i$ синдрому подразненого кишечника. Встановлені гендерні, вікові особливості та варіанти перебігу СПК при різних стадіях $і$ типах загострення ХОЗЛ та БА, взаємообтяжливий вплив поєднаної патологї̈, що потребує адекватної корекиї̈ вже існуючих стандартів діагностики та лікування

Ключові слова: синдром подразненого кишечника, хронічна бронхообструктивна патологія

The paper deals with the clinical course of frequent comorbid diseases - chronic obstructive pulmonary disease, bronchial asthma and irritable bowel syndrome. There were established gender and age peculiarities and variants of course IBS at different stages and types of exacerbation of COPD and BA, codeteriorative impact of comorbidity that requires an adequate correction of existing standards of diagnosis and treatment Keywords: irritable bowel syndrome, chronic broncho-obstructive pathology

\section{1. Вступ}

В теперішній час більшість хронічних хвороб внутрішніх органів характеризуються ко- або поліморбідністю у одного хворого [1]. Синергізм несприятливої дії на організм окремих патологічних станів значно змінює клінічну картину кожного з них [2]. Все це створює труднощі як при встановленні клінічного діагнозу, так i, особливо, при проведенні 
лікування таких пацієнтів [3]. Поєднання захворювань шлунково-кишкового тракту (ШКТ) із бронхіальною астмою (БА) i хронічним обструктивним захворюванням легень (ХОЗЛ) найбільш часто зустрічаються в клінічній практиці і мають взаємообтяжуючий перебіг [4]. Системне запалення при ХОЗЛ та БА, антибіотикотерапія, в разі інфекційного загострення, негативно впливають на перебіг СПК, викликаючи посилення больового синдрому, діареї, здуття живота $[5,6]$. Терапія інфекційних загострень ХОЗЛ або БА, поєднаних із СПК, із застосуванням антибіотиків може погіршити перебіг СПК, змінити мікробіотоп кишечнику та функціонування його слизового бар'єру (СБ) [7]. Проте, вікові особливості, варіанти перебігу СПК при різних стадіях і типах загострення ХОЗЛ та БА вивчені недостатньо.

\section{2. Актуальність теми}

В останнє десятиріччя спостерігається стійка тенденція щодо зростання захворюваності на ХОЗЛ та БА $[5,6]$.

Значна розповсюдженість, хронічний перебіг, необхідність проведення тривалого - базисного лікування роблять частим поєднання ХОЗЛ та БА із захворюваннями шлунково-кишкового тракту (ШКТ) [8, 9].

Антропогенне забруднення біосфери, урбанізація, алергізація, патогенна контамінація слизових оболонок, зростаючий вплив несприятливих зовнішніх чинників обумовлюють зростання частоти функціональної патології кишечнику, насамперед, синдрому подразненого кишечнику [9]. Поєднання захворювань на ХОЗЛ або БА із СПК може ускладнити перебіг обох захворювань, забезпечити толерантність до лікування, погіршити прогноз захворювань дихальної системи $[4,9]$.

Порушення стану слизових бар'єрів бронхів $є$ визначальним у формуванні місцевого та потім системного хронічного запалення при ХОЗЛ і БА, у погіршенні бронхіальної прохідності та розвитку ускладнень [6]. Терапія інфекційних загострень ХОЗЛ або БА, поєднаних із СПК, із застосуванням антибіотиків може погіршити перебіг СПК, змінити мікробіотоп кишечнику та функціонування його слизового бар'єру (СБ) [5, 6]. Проте, особливості порушень у стані СБ, пато- та морфогенез їх розвитку при ХОЗЛ із СПК та БА із СПК вивчений недостатньо.

Значна кількість помилок при діагностиці коморбідної патології, не завжди ефективна терапія поєднаних захворювань призводять до збільшення тривалості непрацездатності, інвалідизації, а, іноді, й до смерті хворих [1].

Все це спонукає до розробки ефективного діагностичного алгоритму поєднання ХОЗЛ і СПК, БА і СПК та до підвищення ефективності їх лікування.

\section{3. Мета дослідження}

Метою роботи було встановлення поширеності та клінічних особливостей перебігу синдрому подразненого кишечника (СПК) у хворих на хронічне обструктивне захворювання легень (ХОЗЛ) та бронхіальну астму (БА). Під спостереженням перебували 300 хворих на ХОЗЛ і БА, що проходили лікування 3 приводу інфекційного загострення у пульмонологічному відділенні Чернівецької обласної клінічної лікарні протягом 2007-2012 рр. Серед них у 98 пацієнтів було діагностовано ХОЗЛ ІІ-ІІІ ступеня тяжкості (I група), у 102 пацієнтів - БА середньотяжкого персистуючого перебігу (II група), у 51 хворих - ХОЗЛ із супутнім СПК (III група), у 49 хворих - БА із супутнім СПК (IV група).

Діагноз та стадію ХОЗЛ, а також діагноз та ступінь тяжкості БА у досліджених хворих було встановлено згідно з наказом МО3 України № 128 [5]. СПК діагностували згідно Римським критеріям III (2006 р.) та вітчизняним протоколам (Наказ МO3 України № 271 від 13.06.2005р.). Для розробки референтної норми були обстежені 50 практично здорових осіб (ПЗО) того ж віку і статі, що дали на це інформовану згоду.

Середній вік хворих I групи складав $(54,2 \pm 4,3)$ роки, серед них жінок було 36 осіб (36,7 \%), чоловіків 62 (63,3\%), стаж паління був $(32,3 \pm 1,1)$ роки; індекс пачко/років складав $(24,3 \pm 4,2)$. Середній вік пацієнтів III групи був $(51,6 \pm 4,1)$ роки, серед них жінок було 18 (35,3\%), чоловіків - 33 (64,7 \%). Стаж паління пацієнтів III групи дорівнював $(33,2 \pm 1,4)$ роки; індекс пачко/років - $(25,1 \pm 3,9)$.

Середній вік хворих II групи становив $(34,6 \pm 4,7)$ років, жінки складали 65,7 \% (67 чол.), чоловіки 34,3 \% (35 чол.). В IV групі були хворі в середньому віці $(32,4 \pm 3,3)$ років, серед них жінки складали 65,3\% (32), чоловіки 34,7 (17 чол.). Серед хворих II та IV груп курцями в минулому були $22(14,6$ \%) хворих, на момент обстеження курців не було в жодній із груп хворих на БА.

Інфекційне загострення у хворих на I та III груп діагностували за рекомендаціями Наказу MO3 України № 128 [5] за наявності посилення задишки, об'єму та гнійності виділяємого харкотиння.

Інфекційне загострення хворим на БА визначали за даними анамнезу - зв'язок із перенесеним напередодні гострим респіраторним вірусним захворюванням, через 5-7 днів після якого знову підвищувалася температура тіла та/або розвивалося загострення середньої тяжкості із почастішанням нападів ядухи, кашлю та утрудненням виділення слизувато-гнійного мокротиння (після виключення пневмонії) (Т. О. Перцева, 2008) [6]. Астма-рахунок визначали за Л. А. Яшиною та співавт. (2003) [7].

\section{4. Результати власних досліджень та їх обговорення}

За результатами верифікації діагнозу поширеність СПК серед хворих на ХОЗЛ та БА, що лікувались стаціонарно з приводу основної патології, склала 1:4. Середній вік хворих I групи складав $(54,2 \pm 4,3)$ роки, серед них жінок було 36 осіб $(36,7 \%)$, чоловіків $62(63,3 \%)$, стаж паління був $(32,3 \pm 1,1)$ роки; індекс пачко/років складав 
$(24,3 \pm 4,2)$. Середній вік пацієнтів III групи був $(51,6 \pm 4,1)$ роки, серед них жінок було 18 (35,3\%), чоловіків - 33 (64,7 \%). Стаж паління пацієнтів III групи дорівнював $(33,2 \pm 1,4)$ роки; індекс пачко/років - $(25,1 \pm 3,9)$.

Середній вік хворих II групи становив $(34,6 \pm 4,7)$ років, жінки складали 65,7 \% (67 чол.), чоловіки $34,3 \%$ (35 чол.). В IV групі були хворі в середньому віці $(32,4 \pm 3,3)$ років, серед них жінки складали 65,3 \% (32 осіб), чоловіки 34,7 \% (17 чол.). Серед хворих II та IV груп курцями в минулому були $22(14,6 \%)$ хворих, на момент обстеження курців не було в жодній із груп хворих на БА. Загострення СПК, що проявлялось скаргами на здуття живота, діарею чи закрепи, абдомінальні болі спостерігалось у всіх хворих із загостреннями основної патології у 100 \% випадків. Хворі пов'язували загострення СПК iз частими загостреннями основної патології, алергічними чинниками при БА та постійним прийомом медикаментів для лікування ХОЗЛ та БА.

При огляді пацієнтів із ХОЗЛ і СПК були чутними дистанційні свистячі хрипи, виявлялася бочкоподібна грудна клітина, ригідна при пальпації. У диханні приймали участь допоміжні м'язи плечового поясу. При перкусії відзначався коробковий перкуторний звук, при аускультації - на фоні послабленого везикулярного дихання поряд із свистячими та дзижчачими хрипами вислуховувалися вологі велико- та середньопухирцеві хрипи. Частота дихальних рухів грудної клітини у пацієнтів була $(24,3 \pm 1,2)$ за 1 хв. Пульс хворих дорівнював $(96,7 \pm 4,5)$ уд. за 1 хв. Пальпація живота у пацієнтів III гр. виявляла загальну болючість живота у 29 хворих (56,9\%), у 32 (62,7\%) - болючість по ходу сигмовидної кишки, у 37 (72,5 \%) здуття живота. У 47 (92,1%) пацієнтів спостерігалися всі вказані симптоми.

При огляді пацієнтів IV гр. під час нападів ядухи також вислуховувалися дистанційні свистячі хрипи, грудна клітина ставала бочкоподібною, перкусія виявляла коробковий звук. При аускультації на фоні ослабленого везикулярного дихання та високотембрових свистячих хрипів вислуховувалися великопухирцеві хрипи. Після нападу ядухи у хворих продовжували вислуховуватися великопухирцеві хрипи, кількість яких зменшувалася після покашлювання. Частота дихальних рухів складала у міжприступний період $(20,7 \pm 1,1)$ за хв., пульс $(92 \pm 3,4)$ уд. за 1 хв. У хворих цієї групи також спостерігалася загальна болючість при пальпації живота у 22 випадках (44,9\%), болючість по ходу сигмовидної кишки - у 19 осіб (38,8 \%), здуття живота - у 41 хворого (83,7 \%). У 33 хворих $(67,3 \%)$ виявлялись всі зазначені симптоми.

В аналізі крові у пацієнтів III гр. відзначався лейкоцитоз із середньою кількістю лейкоцитів $(10,1 \pm 0,9) \times 10^{9} / л$ із наявністю $(7,6 \pm 0,6)$ \% паличкоядерних нейтрофілів. У пацієнтів I гр. вміст лейкоцитів був дещо нижчим - $(9,7 \pm 0,6) \times 10^{9} / л$. Швидкість зсідання еритроцитів у хворих III гр. становила $(23,3 \pm 2,1)$ мм/год., а у пацієнтів I гр. $(21,9 \pm 2,7)$ мм/год. В аналізі харкотиння відзначалися нейтрофільні лейкоцити на все поле зору.

У пацієнтів IV гр. в аналіз крові відзначався лейкоцитоз із середньою кількістю лейкоцитів $(9,2 \pm 0,7) \times 10^{9} / л$ із наявністю $(6,6 \pm 0,8)$ \% паличкоядерних нейтрофілів та $(6,3 \pm 0,4) \%$ еозинофілів. У пацієнтів II гр. вміст лейкоцитів був також дещо нижчим - $(8,4 \pm 0,8) \times 10^{9}$ /л. Швидкість зсідання еритроцитів у хворих IV гр. дорівнювала $(18,2 \pm 1,6)$ мм/год, а у пацієнтів II гр. - $(17,4 \pm 0,9)$ мм/год. В аналізі харкотиння у хворих II групи серед нейтрофільних лейкоцитів та поодиноких макрофагів зустрічалися еозинофіли у кількості до 20-35 клітин, спіралі Куршмана та кристали Шарко-Лейдена, у хворих IV групи в аналізі харкотиння серед нейтрофільних лейкоцитів були наявними поодинокі еозинофіли та спіралі Куршмана.

Рентгенологічне дослідження у жодного хворого не виявляло ознак пневмонії. При цьому у хворих I та III груп спостерігалися емфізема легень та пневмофіброз обмежений - відповідно у 48 (52,1\%) та у 23 (45,1 \%) випадках і полісегментарний - відповідно у 47 (47,9 \%) та 28 (54,9\%) досліджених.

Емфізема легень виявлялася у 18 (17,6 \%) хворих II групи та у 10 (19,6 \%) обстежених IV групи. Обмежений пневмофіброз спостерігався у 12 $(11,8 \%)$ пацієнтів II групи, та полісегментарний - у 9 (18,4 \%) осіб IV групи.

За результатами дослідження у хворих всіх груп, що лікувалися в стаціонарі, був виявлений загально-інтоксикаційний синдром, що проявлявся підвищенням температури тіла до $37,5-38,2{ }^{\circ} \mathrm{C}$ у 66 пацієнтів (67,3\%) I групи і у 36 (70,6 \% хворих) III групи, а також - пітливістю, загальною слабкістю, нетривалим головним болем у всіх хворих I та III груп.

У досліджених із БА підвищення температури тіла спостерігалося у 40 випадках $(39,2 \%)$, БА із СПК - у 20 (42,8\%). У всіх пацієнтів із ХОЗЛ та ХОЗЛ із СПК діагностувався синдром дихальних розладів, який характеризувався кашлем, що турбував їх з ранку до вечора із виділенням значної кількості - до 30-50 мЛ в'язкого мокротиння жовтого, жовто-зеленого або сіруватого кольору, задишкою при незначному фізичному навантаженні, відчуттям постійної тяжкості в грудній клітині, саднінням за грудиною.

У пацієнтів із БА синдром дихальних розладів, проявлявся нападами ядухи вдень та вночі, появою задишки при незначному фізичному навантаженні, приступ задишки закінчувався виділенням слизуватожовтого мокротиння після інгаляції короткодіючого бронхолітика.

Астма-рахунок у пацієнтів IV групи дорівнював $(13,9 \pm 1,2)$ бали, що було незначно вище

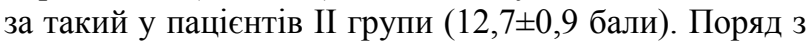
цим у всіх пацієнтів III та IV груп відзначався абдомінальний синдром, який 3'являвся, в середньому, на 3-4-й день лікування загострення i проявлявся здуттям живота у 39 (76,5 \%) хворих у III групі, та у 40 (81,6 \%) пацієнтів із IV групи, болем у животі - відповідно у 37 (72,5 \%) хворих III групи та 
у 36 (73,4 \%) осіб IV групи, діареєю у 4 (7,8 \%) випадках у III групі та у 10 (20,4 \%) осіб IV групи, закрепами - у 7 (13,7 \%) досліджених III групи та 28 (57,1\%) обстежених IV групи, змішаний тип СПК спостерігався у 37 (72,5\%) пацієнтів III групи та у 9 (18,4 \%) досліджених IV групи. Недиференційований тип СПК у хворих III та IV груп діагностувався відповідно у 3 (5,8 \%) та у 10 (20,4\%) випадків.

При порівняльному аналізу вікового розподілу хворих із ХОЗЛ, БА та СПК встановлено, що найчастіше СПК у пацієнтів із ХОЗЛ спостерігається у віковому проміжку 46-55 років, що співпадає 3 середнім віком хворих на ХОЗЛ, які активно звертаються за медичною допомогою, та наявністю у даної категорії пацієнтів значимої задишки та дихальної недостатності, частих загострень ХОЗЛ.

Найбільша кількість хворих БА 3 СПК спостерігається у віці 36-45 років, поступово зменшуючись у віці 46-55 років, досягаючи свого мінімуму у віці 56-65 років, та знову зростаючи у віці понад 65 років, що, ймовірно, пов'язано із віковим зниженням компенсаторних механізмів організму, тривалістю основного захворювання та розвитком ускладнень i значимого ступеню дихальної недостатності. У групах хворих на ХОЗЛ та БА без СПК і за наявності СПК віковий склад достовірно не відрізнявся, що дозволяє вважати ці групи співставними ( $>0,05)$. Вік обстежених хворих на ХОЗЛ та БА з СПК представлено в табл. 1, рис. 1.

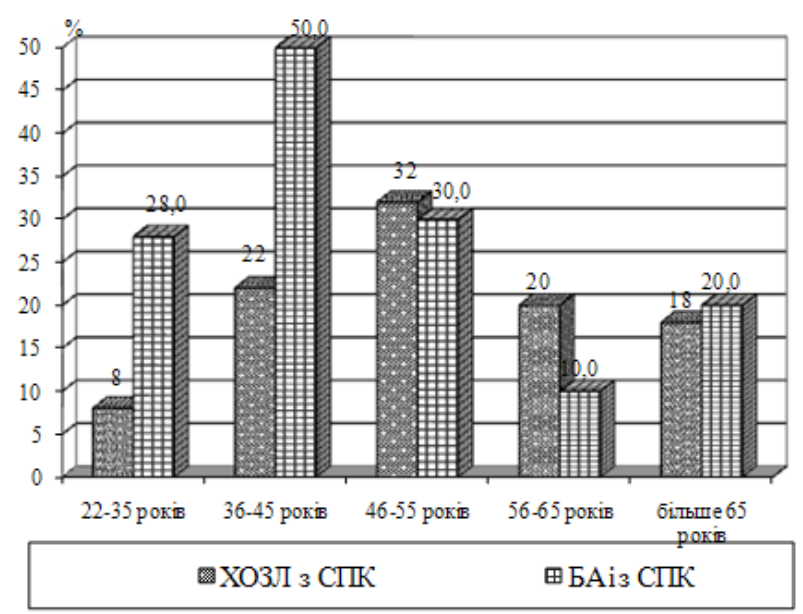

Рис. 1. Частота сполученого синдрому подразненого кишечника (\%) у хворих на ХОЗЛ та БА в залежності від віку

Виникненню СПК, за результатами дослідження, у більшості випадків, передував тривалий, за даними анамнезу, більше 5 років, перебіг ХОЗЛ чи БА.
Давність поєднаної патології становила від 7 місяців до 10 років, в середньому складала $6,0 \pm 0,5$ року: 5 хворих (5\%) хворіли на сполучену патологію до 1 року; 26 пацієнти (26\%) - від 1 до 5 років; 52 (52\%) хворих - від 6 до 10 років та 17 (17\%) пацієнтів більше 10 років (рис. 2).

Таблиця 1

Віковий розподіл обстежених хворих на ХОЗЛ та БА в сполученні з СПК

\begin{tabular}{|c|c|c|}
\hline $\begin{array}{c}\text { Вік хворих } \\
\text { (роки) }\end{array}$ & \multicolumn{2}{|c|}{ Частота СПК абс (\%) } \\
\hline & ХОЗЛ $(\mathrm{n}=51)$ & БА $(\mathrm{n}=49)$ \\
\hline $20-35$ & $3(5,88 \%)$ & $5(8,47 \%)$ \\
\hline $36-45$ & $5(9,8 \%)$ & $7(14,28 \%)$ \\
\hline $46-55$ & $25(49,01 \%)$ & $24(48,97 \%)$ \\
\hline $56-65$ & $16(31,37 \%)$ & $7(14,28 \%)$ \\
\hline Старше 65 & $2(3,92 \%)$ & $6(12,24 \%)$ \\
\hline
\end{tabular}

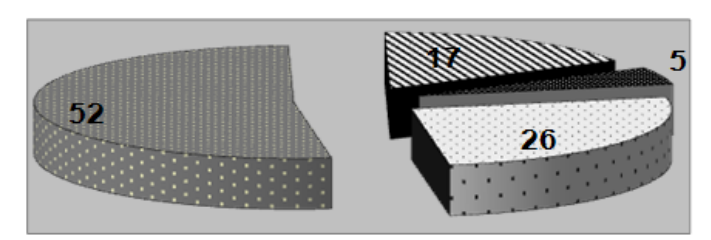

До1 року 口1-5 років

Рис. 2. Розподіл хворих на поєднану патологію в залежності від тривалості основного захворювання

Характерно, що у хворих на ХОЗЛ $з$ віком відбувалося поступове зменшення випадків супутнього СПК, досягаючи свого мінімуму у віці старше 65 років на противагу хворим на БА із СПК. Практично однаковою $є$ кількість випадків СПК у пацієнтів на ХОЗЛ та БА у віці 46-55 років (25 та 24 відповідно), що ймовірно пов'язано із активним прогресуванням основної патології, частими загостреннями, розвитком дихальної недостатності, працездатним віком хворих, постійним прийомом ліків та спільними механізмами загострення СПК при загостренні основного захворювання.

У молодому віці СПК рідко зустрічалося при ХОЗЛ, але активно виявлявся у хворих на БА. Отже, можна зробити висновки, що СПК найбільш часто зустрічається при БА у віці $36-45$ років та у віці 46-55 років (однаково і при БА і при ХОЗЛ). Частота визначення різних форм СПК у хворих на ХОЗЛ та БА також була відмінною. У групи пацієнтів з ХОЗЛ і СПК домінували хворі 3 III типом СПК (змішаним) - 36 (70,58 \%), на відміну від групи хворих з БА та СПК, де домінували пацієнти з СПК із закрепами 24 (48,9 \%). Інші типи СПК зустрічались однаково часто в обох групах (рис. 3,4$)$. 


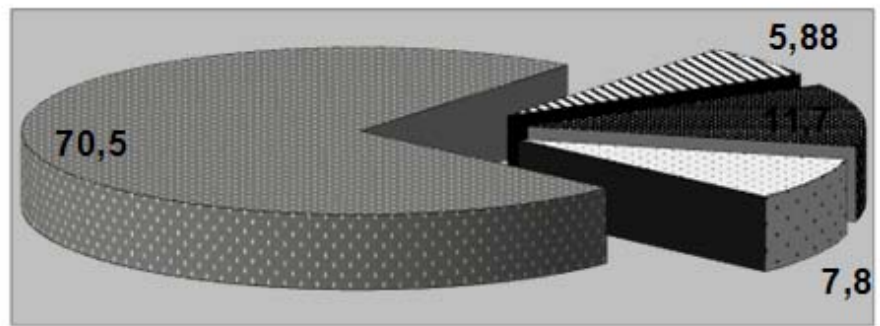

\begin{tabular}{|ll|}
\hline I (із закрепом) & $\square$ II (з діареєю) \\
III (змішаний) & $\mathbf{D I V}$ (недиференційований) \\
\hline
\end{tabular}

Рис. 3. Розподіл типів СПК у хворих на ХОЗЛ (\%)

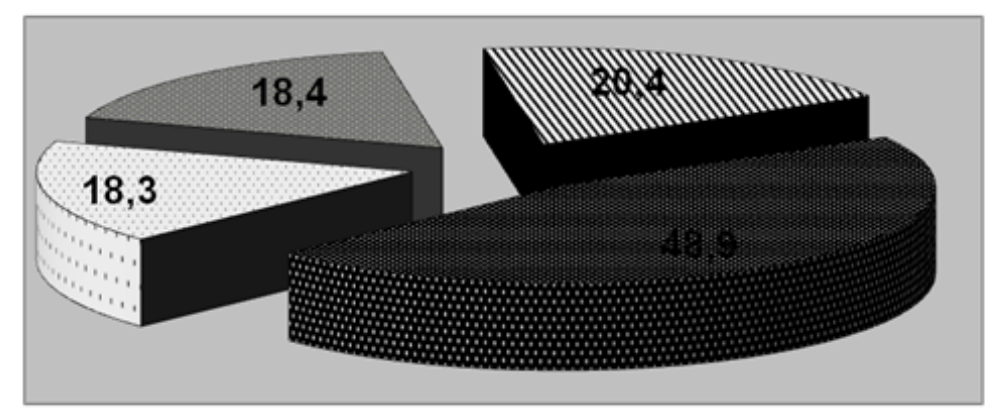

\begin{tabular}{|ll|}
\hline I із закрепом & $\square$ II (з діареєю) \\
$\square$ III (змішангй) & $\mathbb{8}$ IV (недпференщійованпй) \\
\hline
\end{tabular}

Рис. 4. Розподіл типів СПК у хворих на БА (\%)

СПК частіше зустрічався у хворих II та III стадії ХОЗЛ на відміну від хворих з БА, де СПК зустрічався вже з І стадії БА або до встановлення діагнозу БА (рис. 5).

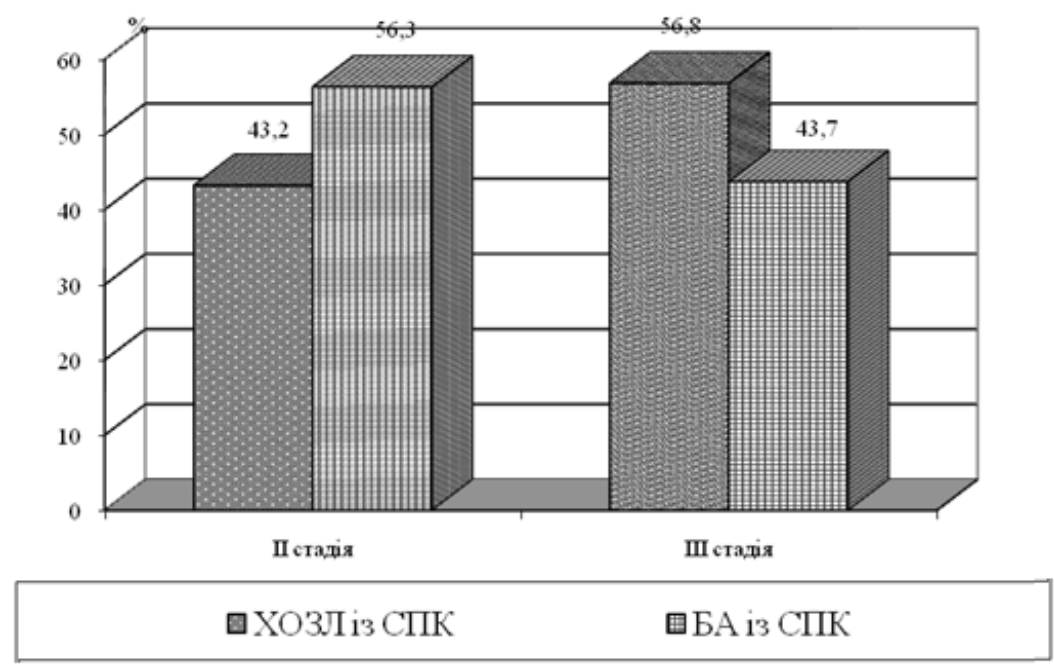

Рис. 5. Частота супутнього синдрому подразненого кишечника у хворих на ХОЗЛ та БА в залежності від важкості перебігу захворювання

Кількість інфекційних загострень на рік у пацієнтів із ХОЗЛ становила $(1,1 \pm 0,2)$, у пацієнтів із ХОЗЛ та СПК - $(1,7 \pm 0,3)$ випадків або у 1,5 рази частіше. У хворих на БА кількість загострень на рік дорівнювала $(2,2 \pm 0,3)$, в т. ч. інфекційних - $(0,3 \pm 0,1)$, БА із СПК $(2,9 \pm 0,2)$ рази, в т. ч. інфекційних - дещо частіше - $(0,6 \pm 0,2)$ рази. Загальна кількість 
загострень у пацієнтів із БА та СПК була у 1,3 рази більше, ніж у пацієнтів із БА без СПК.

Важчий перебіг СПК зустрічався у хворих на ХОЗЛ із частими інфекційними загостреннями I типу за Антонісеном ( $\geq 4$ за рік), що потребували призначення антибактеріальної терапії. У хворих на БА важчий перебіг СПК спостерігався переважно у молодих жінок з обтяженим алергологічним та/або спадковим анамнезом і не залежав від тривалості захворювання. Загострення СПК корелювали із загостреннями БА та ХОЗЛ у 100 \% випадках.

Патогенетична основа патологічних процесів в травному тракті при ХОЗЛ та БА має багато спільного. Відмічено важливе значення алергії, а саме позалегеневих іiі проявів, головним чином при БА. При ХОЗЛ цей взаємозв'язок прослідковується меншою мірою (табл. 2).

Таблиця 2

Клініко-патогенетичні особливості співставлення при БА та ХОЗЛ із СПК (\%)

\begin{tabular}{|l|c|c|c|}
\hline \multicolumn{1}{|c|}{ Показники } & БА з СПК $(\mathrm{n}=49)$ & ХОЗЛ з СПК $(\mathrm{n}=51)$ & Різниця (\%) \\
\hline Чоловіки & 44,12 & 48,11 & $-3,99$ \\
\hline Старше 46 років & 46,1 & 86,2 & $-40,1$ \\
\hline Загострення СПК & 100,0 & 100,0 & 0 \\
\hline Позалегеневі прояви алергії & 21,13 & 2,3 & 18,83 \\
\hline Виникнення пізніше захворювань легень & 78,13 & 86,13 & $-8,0$ \\
\hline Виникнення одночасно із захворюваннями легень & 2,15 & 1,16 & 0,99 \\
\hline Виникнення раніше захворювань легень & 19,12 & 12,12 & 7,0 \\
\hline Паління & 56,1 & 98,3 & $-42,2$ \\
\hline Лікування СПК & 18,2 & 11,4 & 6,8 \\
\hline
\end{tabular}

Тривала інтоксикація, що більш характерна для ХОЗЛ, є підгрунтям субатрофічних та ерозивних процесів в слизових оболонках бронхів та кишечника, з розвитком порушень функціонування слизових бар'єрів.

Таким чином, СПК частіше спостерігається у жінок з БА, молодших 46 років, у 21,3 \% 3 позалегеневими проявами алергії і виникає пізніше захворювань легень. Велике значення для виникнення сполученого СПК має і стаж паління - у хворих на ХОЗЛ у 98 \% випадків, у хворих на БА у $56 \%$ випадків. Хворі з ХОЗЛ та БА звертались до лікаря з приводу симптомів СПК не часто - у $11 \%$ та $18 \%$ випадків. Аналіз результатів проведеного дослідження вказує на те, що поширеність СПК у хворих із ХОЗЛ та БА, які лікувались стаціонарно, складає 1:4. Загострення СПК корелювали із загостреннями БА та ХОЗЛ у $100 \%$ випадках. Виявлено незначне переважання частоти зустрічання СПК у хворих на ХОЗЛ у порівнянні із хворими на БА. Частота зустрічання СПК в залежності від віку хворих відрізнялась при ХОЗЛ та БА у бік більш старшого віку при ХОЗЛ.

Вік пацієнтів із ХОЗЛ та СПК був в середньому на $7 \pm 3$ роки старшим, ніж у хворих на БА iз СПК. Давність поєднаної патології становила від 7 місяців до 10 років, в середньому - 6,0 $\pm 0,5$ року: 4,7 \% хворіли на сполучену патологію до 1 року; $51,9 \%$ - від 1 до 5 років; 43,4 \% - від 6 до 10 років. СПК найбільш часто зустрічався у хворих на БА у віці 36-45 років та у віці 46-55 років однаково, і при БА і при ХОЗЛ.

Відмічено наявність залежності частоти СПК від стадії ХОЗЛ на відміну від хворих з БА, де СПК зустрічався вже 3 I ступеня тяжкості БА або до встановлення діагнозу БА. Встановлено негативний вПлив частих інфекційних загострень ХОЗЛ та призначення антибактеріальної терапії, статі і віку хворих із БА на клінічний перебіг СПК. Залежність тяжкості перебігу СПК від тривалості основної патології відмічено у хворих на ХОЗЛ. Розвиток виявленого СПК, очевидно, пов'язаний з системним впливом запального процесу при ХОЗЛ та БА на стан СБ організму, в тому числі кишечника. Симптоми СПК у хворих із інфекційним загостренням ХОЗЛ характеризувалися більш вираженим больовим абдомінальним i диспепсичним синдромами, i потребували медикаментозної корекції.

Поряд із констатацією ознак, більш характерних для ХОЗЛ (більша частота чоловіків, старше 46 років), слід відмітити, що у $100 \%$ пацієнтів загострення основного захворювання супроводжувалося і загостренням СПК.

Скарги на здуття живота, діарею чи закрепи та абдомінальні болі хворі пов'язували із частими загостреннями основної патології та прийомом медикаментів. Виникненню СПК у даної категорії хворих передував тривалий, за даними анамнезу, більше 5 років, перебіг ХОЗЛ чи БА. Всі хворі на ХОЗЛ та БА відмічали більше одного загострення захворювання за останній рік. Серед них $42 \%$ пацієнтів відмічали 4 та більше загострення за останній рік, клінічна картина ХОЗЛ і БА у яких була найбільш важкою.

\section{5. Висновки}

Клінічний перебіг інфекційного загострення ХОЗЛ із СПК та БА із СПК характеризується наявністю загально-інтоксикаційного синдрому, синдрому дихальних розладів та абдомінального - у всіх хворих із переважанням закрепів при поєднанні БА і СПК та змішаного типу СПК у пацієнтів із ХОЗЛ. У пацієнтів із ХОЗЛ та СПК інфекційні загострення відзначаються у 1,5 рази частіше, у Хворих на БА з СПК - у 1,3 рази, ніж у осіб на ХОЗЛ 
i БА відповідно. Загострення СПК завжди відзначаються в період загострень ХОЗЛ і БА.

\section{Лiтература}

1. Grosdidier, S. Network medicine analysis of COPD multimorbidities [Text] / S. Grosdidier, A. Ferrer, R. Faner et al. // Respiratory Research. 2014. - Vol. 15, Issue 1. - P. 111. doi: 10.1186/s12931014-0111-4

2. Rabinovich, R. A. Chronic obstructive pulmonary disease and its comorbidities [Text] / R. A. Rabinovich, W. MacNee // British Journal of Hospital Medicine. - 2011. - Vol. 72, Issue 3. - P. 137-145. doi: 10.12968/hmed.2011.72.3.137

3. Bassett, J. T. A review of irritable bowel syndrome and an update on therapeutic approaches [Text] / J. T. Bassett, D. C. Brooks // Expert Opinion on Pharmacotherapy. - 2008. - Vol. 9, Issue 7. P. 1129-1143. doi: 10.1517/14656566.9.7.1129

4. Cole, J. A. Incidence of IBS in a cohort of people with asthma [Text] / J. A. Cole, K. J. Rothman, H. J. Cabral, Y. Zhang, F. A. Farraye // Digestive Diseases and Sciences. - 2007. - Vol. 52, Issue 2. P. 329-335. doi: 10.1007/s10620-006-9530-5

5. Pertseva, T. A. Infektsionnoye obostreniye bronkhialnoy astmy [Text] / T. A. Pertseva // Zdorov'ya Ukraini. - 2008. - Vol. 3/1. - P. 6.

6. Avdeyev, C. Sistemnye effekty u bolnykh KhOBL [Text] / C. Avdeyev // Vrach. - 2006. - № 12. P. 3-8.

7. Diagnostika i lecheniye zabolevany pishchevaritelnogo trakta: Uch. posobiye [Text] / Pod red. prof. A.E. Dorofeyeva. - Donetsk: Nord-Press, 2009. -366 p.

8. Sin, D. D. Mortality in COPD: role of comorbidities [Text] / D. D. Sin, N. R. Anthonisen, J. B. Soriano, A. G. Agusti, // European Respiratory Journal. - 2006. - Vol. 28, Issue 6. - P. 45-57. doi: 10.1183/09031936.00133805

9. Panicker, R. Association and symptom characteristics of irritable bowel syndrome among bronchial asthma patients in Kuwait [Text] / R. Panicker, N. Arifhodzic, M. Al Ahmad, S. Ali // Annals of Thoracic Medicine. - 2010. - Vol. 5, Issue 1. - P. 37-42. doi: 10.4103/1817-1737.58958

10. Drossman, D. A. The Functional Gastrointestinal Disorders and the Rome III Process [Text] / D. A. Drossman // Gastroenterology. - 2006. -
Vol. 130, Issue 5. - $\quad$ P. 1377-1390. doi: $10.1053 /$ j.gastro.2006.03.008

11. Nakaz MOZ Ukraïni vid 19.03.2007r. №128 «Pro zatverdzhennya klinichnikh protokoliv nadannya medichnoï dopomogi za spetsialnistyu «Pulmonologiya» [Electronic resource] / Available at: www.ifp.kiev.ua

\section{References}

1. Grosdidier, S., Ferrer, A., Faner, R. (2014). Network medicine analysis of COPD multimorbidities. Respiratory Research, 15 (1), 111. doi: 10.1186/s12931014-0111-4

2. Rabinovich, R. A., MacNee, W. (2011). Chronic obstructive pulmonary disease and its comorbidities. British Journal of Hospital Medicine, 72 (3), 137-145. doi: 10.12968/hmed.2011.72.3.137

3. Bassett, J. T., Brooks, D. C. (2008). A review of irritable bowel syndrome and an update on therapeutic approaches. Expert Opinion on Pharmacotherapy, 9 (7), 1129-1143. doi: 10.1517/14656566.9.7.1129

4. Cole, J. A., Rothman, K. J., Cabral, H. J., Zhang, Y., Farraye, F. A. (2007). Incidence of IBS in a cohort of people with asthma. Digestive Diseases and Sciences, 52 (2), 329-335. doi: 10.1007/s10620-0069530-5

5. Pertseva, T. A. (2008). Infektsionnoye obostreniye bronkhialnoy astmy. Zdorov'ya Ukraïni, $3(1), 6$.

6. Avdeyev, C. (2006). Sistemnye effekty u bolnykh KhOBL, Vrach, 12, 3-8.

7. Dorofeyev, A. E. (2009). Diagnostika i lecheniye zabolevany pishchevaritelnogo trakta, 366.

8. Sin, D. D., Anthonisen, N. R., Soriano, J. B., Agusti, A. G. (2006). Mortality in COPD: role of comorbidities, European Respiratory Journal, 28 (6), 45-57. doi: 10.1183/09031936.00133805

9. Panicker, R., Arifhodzic, N., Al Ahmad, M., Ali, S. (2010). Association and symptom characteristics of irritable bowel syndrome among bronchial asthma patients in Kuwait, Annals of Thoracic Medicine, 5 (1), 37-42. doi: 10.4103/1817-1737.58958

10. Drossman, D. A. (2006). The Functional Gastrointestinal Disorders and the Rome III Process, Gastroenterology, $130 \quad$ (5), 1377-1390. doi: 10.1053/j.gastro.2006.03.008

11. Nakaz MOZ Ukraïni (2007). № 128 «Pro zatverdzhennya klinichnikh protokoliv nadannya medichnoï dopomogi za spetsialnistyu «Pulmonologiya». Available at: www.ifp.kiev.ua

Коваленко Світлана Вікторівна, доктор медичних наук, доцент, кафедра внутрішньої медицини, Буковинський державний медичний університет, пл. Театральна, 2, м. Чернівці, Україна, 58000 E-mail: cvetko@ukr.net 